\title{
Validation of a job aid to rule out pregnancy among family planning clients in Nicaragua
}

\author{
John Stanback, ${ }^{1}$ Kavita Nanda, ${ }^{1}$ Yolanda Ramirez, ${ }^{2}$ \\ Wes Rountree, ${ }^{1}$ and Sandra B. Cameron ${ }^{1}$
}

Suggested citation Stanback J, Nanda K, Ramirez Y, Rountree W, Cameron SB. Validation of a job aid to rule out pregnancy among family planning clients in Nicaragua. Rev Panam Salud Publica. 2008;23(2):116-8.

\begin{abstract}
In Latin America, one of the most common barriers to family planning access is denial of services to women who present at clinics in the absence of menses. Where pregnancy tests are unavailable, many providers fear that nonmenstruating women may be pregnant and, worrying about possible harm to the fetus, require the woman to await the onset of menses before initiating a contraceptive method. In 2005, during a randomized trial of oral contraceptive users in Nicaragua, we assessed a job aid endorsed by the World Health Organization to help providers exclude pregnancy among family planning clients. Among 263 new, nonmenstruating clients, the job aid ruled out pregnancy for $60 \%$ of the women. Only $1 \%$ of the women were pregnant, and no woman identified by the job aid as "not pregnant" was pregnant. Provider fears that nonmenstruating clients are pregnant are usually misplaced, while fears that hormonal methods can harm fetuses are exaggerated.
\end{abstract}

Key words Family planning services, pregnancy, Nicaragua.

Denial of contraception to nonmenstruating women is a common barrier to family planning services in many parts of the world, particularly where pregnancy tests are unavailable or unaffordable (1). In a recent study in Guatemala, for example, $16 \%$ of all new family planning clients were denied services because of the absence of menses (2). Behind the problem of

\footnotetext{
1 Family Health International, Health Services Research, PO Box 13950, Research Triangle Park 27709 , NC, United States of America. Send correspondence and reprint requests to: John Stanback, Family Health International, Health Services Research, PO Box 13950, Research Triangle Park 27709, NC, United States of America; telephone (919) 544-7040; fax (919) 544-7261; e-mail: jstanback@fhi.org.

2 Hospital "Bertha Calderón Roque", Managua, Nicaragua.
}

menstruation requirements lie provider fears that contraception can harm an unrecognized pregnancy. This fear is legitimate in the case of the intrauterine device but is exaggerated in the case of hormonal methods. According to the World Health Organization (WHO), there is good evidence that hormonal methods will not harm a fetus if they are accidentally initiated during pregnancy (3).

Sending family planning clients home without a contraceptive method is rarely necessary. An algorithm for excluding pregnancy was developed in the early 1990s and now is included in many international guidance documents, including consensus recommendations published by WHO (4).
The algorithm consists of six criteria, meeting any one of which is sufficient to be "reasonably certain that the woman is not pregnant." A job aid (Figure 1) based on the WHO criteria was developed in the late 1990s; it was found to be very effective in Kenyan and Egyptian family planning clinics, primarily because very few new clients $(\sim 1 \%)$ presented for services while pregnant $(5,6)$.

The job aid consists of six questions related to most recent birth, duration and frequency of breast-feeding, last menstrual period, abortion or miscarriage, sexual relations, and current contraception. If the woman answers "yes" to any of the questions and is free of signs or symptoms of preg- 


\section{FIGURE 1. Checklist to rule out pregnancy}

How to be Reasonably Sure a Client is Not Pregnant

Ask the client questions 1-6. As soon as the client answers YES to any question, stop, and follow the instructions.

\begin{tabular}{|c|c|c|c|}
\hline NO & & $\begin{array}{l}\text { Did you have a baby less than } 6 \text { months } \\
\text { ago, are you fully or nearly-fully } \\
\text { breastfeeding, and have you had no } \\
\text { menstrual period since then? }\end{array}$ & YES \\
\hline NO & 2. & $\begin{array}{l}\text { Have you abstained from sexual } \\
\text { intercourse since your last menstrual } \\
\text { period or delivery? }\end{array}$ & YES \\
\hline NO & 3. & Have you had a baby in the last 4 weeks? & YES \\
\hline NO & 4. & $\begin{array}{l}\text { Did your menstrual period start within } \\
\text { the past } 7 \text { days (or within the past } \\
12 \text { days if you are planning to use an IUD)? }\end{array}$ & YES \\
\hline NO & 5. & $\begin{array}{l}\text { Have you had a miscarriage or abortion } \\
\text { in the past } 7 \text { days (or within the past } 12 \\
\text { days if you are planning to use an IUD)? }\end{array}$ & YES \\
\hline NO & 6. & $\begin{array}{l}\text { Have you been using a reliable } \\
\text { contraceptive method consistently and } \\
\text { correctly? }\end{array}$ & YES \\
\hline
\end{tabular}

If the client answered NO to all of the questions, pregnancy cannot be ruled out. Client should await menses or use a pregnancy test.
If the client answered YES to at least one of the questions, and she is free of signs or symptoms of pregnancy, provide client with desired method.

TABLE 1. Validity of checklist $^{\mathrm{a}}$

\begin{tabular}{lccc}
\hline & \multicolumn{2}{c}{ Urine pregnancy test } & \\
\cline { 2 - 3 } \multicolumn{1}{c}{ Job aid } & Pregnant & Not pregnant & Total \\
\hline Pregnant & 3 & 103 & 106 \\
Not pregnant & 0 & 157 & 157 \\
Total & 3 & 260 & 263 \\
\hline
\end{tabular}

a Sensitivity $=100 \%(95 \%$ confidence interval, 29-100). Specificity $=60 \%(54 \%-66 \%)$. Positive predictive value $=3 \%(1 \%-8 \%)$. Negative predictive value $=100 \%(98 \%-100 \%)$.

nancy, it can be assumed she is not pregnant. Although the job aid-often called the "pregnancy checklist"- has been introduced in several forms to Latin America and even shown in research in Guatemala (2) to reduce family planning denial rates by almost $90 \%$, it has never been validated in the region and shown to be effective at ruling out pregnancy among women normally at risk for service denial.

We assessed the job aid during admission screening for a randomized trial comparing two approaches to provision of oral contraceptives. The trial, conducted with the Asociación Pro-Bienestar de la Familia Nicaragüense (PROFAMILIA) in Managua,
Nicaragua, in 2005, has been described elsewhere (7). To test the validity of the job aid, we administered it and followed up with a commercial dipstick urine pregnancy test to 263 new, nonmenstruating family planning clients desiring oral contraception (Table 1). The checklist ruled out pregnancy for $60 \%$ of the women, somewhat less than the $88 \%$ and $83 \%$ specificity found in Kenya and Egypt, respectively. This lower specificity was likely due to the nature of the ongoing clinical trial, which excluded postpartum clients for whom pregnancy might have been easily ruled out by lactational infecundability. The earlier assessments in Kenya and Egypt included many such postpartum clients.

Interestingly, the pregnancy test detected pregnancies in $1 \%$ of women, the same prevalence found in Kenya and Egypt. With the dipstick pregnancy test as the reference standard, the sensitivity of the job aid was $100 \%$; the positive predictive value was $3 \%$, and the negative predictive value of the job aid was $100 \%$.

One weakness of the study was its limited sample size, which, because of the rarity of pregnancy, resulted in an unstable estimate for the job aid's sensitivity. However, we contend that the relevant statistic for family planning programs is the job aid's high (and stable) negative predictive value $(100 \%)$. No woman identified by the job aid as "not pregnant" was pregnant. Given the rarity of pregnancy documented among new, nonmenstruating family planning clients in Nicaragua and elsewhere, providers should stop the practice of routinely denying services to nonmenstruating clients. Instead, they should make efforts to ensure that every new family planning client leaves the clinic with an effective method. Widespread use of this job aid, with recourse to pregnancy tests when necessary, could reduce a serious barrier to contraceptive access in many Latin American countries.

Acknowledgment. Funding for this study was provided by the United States Agency for International Development. 


\section{REFERENCES}

1. Shelton JD, Angle MA, Jacobstein RA. Medical barriers to access to family planning. Lancet. 1992;340(8831):1334-5.

2. Stanback J, Diabate F, Dieng T, de Morales TD, Cummings $S$, Traoré M. Ruling out pregnancy among family planning clients: the impact of a checklist in three countries. Stud Fam Plann. 2005;36(4):311-5.

3. World Health Organization, Department of Reproductive Health and Research, and Johns Hopkins Bloomberg School of Public Health/ Center for Communications Programs. Family planning: a global handbook for provid- ers. Geneva and Baltimore: WHO and CCP; 2007.

4. World Health Organization. Selected practice recommendations for contraceptive use. Geneva: WHO; 2004.

5. Stanback J, Qureshi Z, Sekadde-Kigondu C, Gonzalez B, Nutley T. Checklist for ruling out pregnancy among family-planning clients in primary care. Lancet. 1999;354(9178):566.

6. Hassan EO, Stanback J, Eldamanhoury H. Validation of the pregnancy checklist in selected Egyptian family planning centers. Cairo: Egyptian Fertility Care Foundation; 2005.
7. Nanda K, Stanback J, Rountree RW, Cameron SB. Randomized trial of 'quick start' versus advance provision of oral contraceptive pills in Nicaragua. Annual Conference of the American College of Obstetrics and Gynecology. Obstet Gynecol. 2006;107:50S.

Manuscript received 18 September 2007. Revised version accepted for publication on 11 January 2008.

RESUMEN En América Latina, uno de los obstáculos más frecuentes para acceder a los servicios de planificación familiar es la negativa a atender a las mujeres que se presentan en las clínicas sin menstruación. Cuando no hay pruebas de embarazo disponibles, muchos profesionales piensan que las mujeres sin menstruación visible pueden estar embarazadas y por temor a ocasionar algún daño al feto les exigen esperar hasta el inicio de la menstruación para comenzar con algún método anticonceptivo. En 2005, durante un ensayo aleatorizado con usuarias de anticonceptivos orales en Nicaragua, se evaluó una lista de verificación avalada por la Organización Mundial de la Salud para ayudar a los profesionales sanitarios a descartar el embarazo en las mujeres que solicitan servicios de planificación familiar. Este procedimiento permitió descartar el embarazo en $60 \%$ de las 263 mujeres sin menstruación que solicitaban por primera vez ese servicio. Solamente $1 \%$ de las mujeres estaban embarazadas y ninguna de las identificadas por este procedimiento como "no embarazada" lo estaba. El temor de los profesionales de la salud de que las mujeres sin menstruación estén embarazadas es frecuentemente infundado y los temores de que los métodos hormonales puedan dañar al feto son exagerados.

Palabras clave Servicios de planificación familiar, embarazo, Nicaragua.

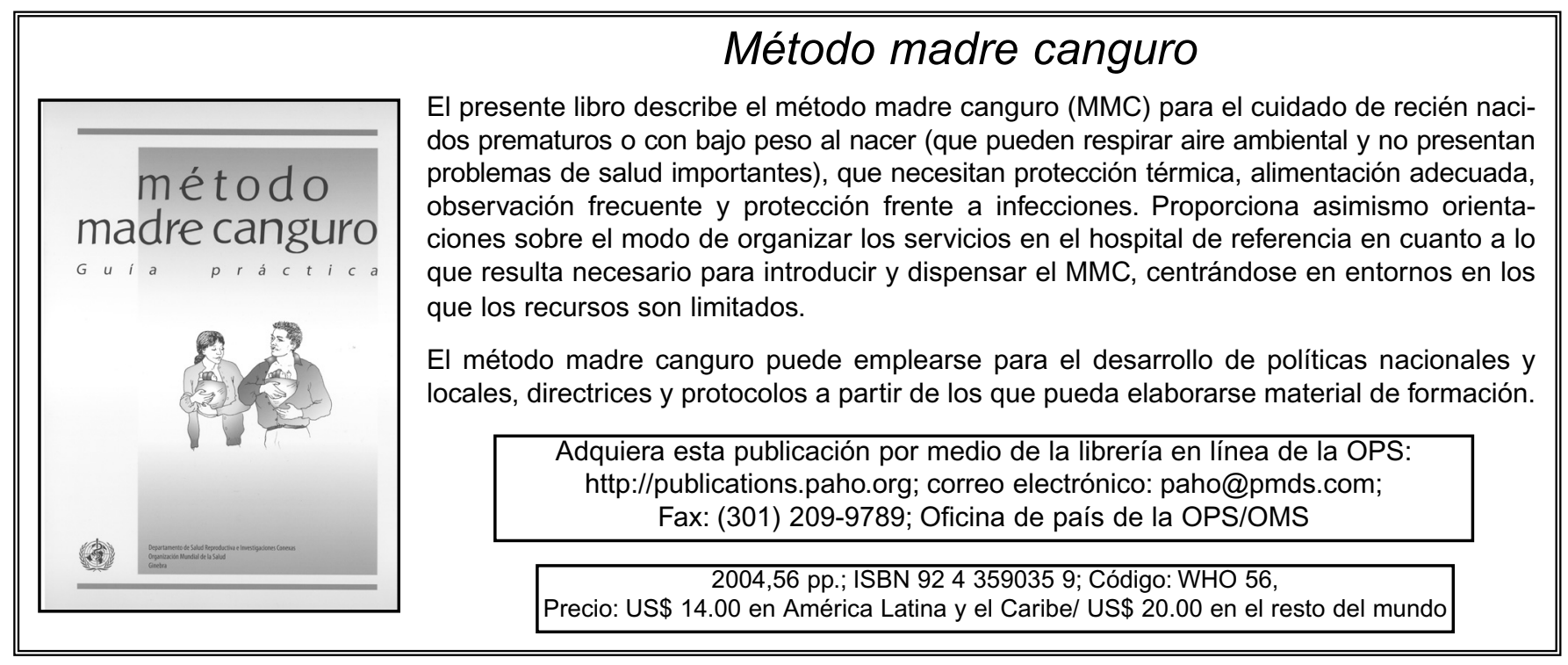

